\title{
Inhibition of HIV-1 enzymes, antioxidant and anti-inflammatory activities of
}

\section{Plectranthus barbatus}

Petrina Kapewangolo ${ }^{a}$, Ahmed A. Hussein ${ }^{b}$ and Debra Meyer ${ }^{a *}$

${ }^{a}$ Department of Biochemistry, Faculty of Natural and Agricultural Sciences, University of Pretoria, Hatfield Campus, Pretoria 0002, South Africa.

${ }^{\mathrm{b}}$ Chemistry Department, University of Western Cape, Private Bag X17, Bellville, 7535, Cape town, South Africa.

*Corresponding author. Department of Biochemistry, Faculty of Natural and Agricultural Sciences, University of Pretoria, P/Bag X20, Hatfield 0028, Pretoria, South Africa. Tel.: +27 12420 2300; fax: +27 12362 5302. Email address: Debra.Meyer@up.ac.za (D. Meyer).

\section{Abstract}

Ethnopharmacological relevance

Plectranthus barbatus is widely used in African countries as an herbal remedy to manage HIVIAIDS and related conditions.

\section{Aim of the study}

To investigate the HIV-1 inhibitory, anti-inflammatory and antioxidant properties of $P$. barbatus and thereby provide empirical evidence for the apparent anecdotal success of the extracts.

\section{Materials and methods}

Ethanolic extract of $P$. barbatus's leaves was screened against two HIV-1 enzymes; protease (PR) and reverse transcriptase (RT). Cytotoxicity of the extract was determined through measuring tetrazolium dye uptake of peripheral blood mononuclear cells (PBMCs) and the TZM-bl cell line. Confirmatory assays for cytotoxicity were performed using flow cytometry and real-time cell electronic sensing (RT-CES). The free radical scavenging activity of the extract was investigated with 2,2-diphenyl-1picrylhydrazyl while the anti-inflammatory properties of the plant extract were investigated using a Th1/Th2/Th17 cytometric bead array technique. 


\section{Results}

P. barbatus extract inhibited HIV-1 PR and the $50 \%$ inhibitory concentration $\left(\mathrm{IC}_{50}\right)$ was $62.0 \mu \mathrm{g} / \mathrm{ml}$. The extract demonstrated poor inhibition of HIV-1 RT. Cytotoxicity testing presented $\mathrm{CC}_{50}$ values of 83.7 and $50.4 \mu \mathrm{g} / \mathrm{ml}$ in PBMCs and TZM-bl respectively. In addition, the extract stimulated proliferation in HIV negative and positive PBMCs treated. RT-CES also registered substantial TZM-bl proliferation after extract treatment. The extract exhibited strong antioxidant activity with an $\mathrm{IC}_{50}$ of $16 \mu \mathrm{g} / \mathrm{ml}$ and reduced the production of pro-inflammatory cytokines indicating anti-inflammatory potential.

\section{Conclusion}

This is the first demonstration of the in vitro anti HIV-1 potential of $P$. barbatus including direct activity as well as through the stimulation of protective immune and inflammation responses. The low cytotoxicity of the extract is also in agreement with the vast anecdotal use of this plant in treating various ailments with no reported side-effects.

Keywords: Plectranthus barbatus, HIV-1 protease, HIV-1 reverse transcriptase, antioxidant, cytokines

\section{Introduction}

Plectranthus is a genus that belongs to the Lamiaceae family. This genus is distributed worldwide and contains about 300 species with 45 of these being used ethnobotanically on the African continent (Lukhoba et al., 2006). Plectranthus species has numerous ethnomedicinal uses such as in antibacterial, antiviral, anti-malaria and antifungal phytotherapy (Lukhoba et al., 2006). Plectranthus barabatus Andr. is regarded as one of the most important medicinal species of the genus Plectranthus. $P$. barbatus originated from north-eastern Africa and is found in sub-Saharan Africa as an invasive species (Rice et al., 2011). For centuries it has been used in folk medicine of Brazil, tropical Africa and China as well as in Hindu and Ayurvedic traditional medicine (Lukhoba et al., 2006; Maioli et al., 2010).

$P$. barbatus is used in antispasmodic therapy, where it is specifically used for the treatment of gastric disturbances associated with intestinal spasms (Almeida, 2003). In Kenya, the plant is reportedly used traditionally as antimalarial phytotherapy (Nguta et 
al., 2010a, 2010b). $P$. barbatus has also been reported to be a herbal remedy against candida which was proven in an in vitro pharmacological study (Runyoro et al., 2006).

A number of diterpenoids have been isolated from $P$. barbatus. These are the most common group of compounds found in Plectranthus plants (Abdel-Mogib et al., 2002). The medicinal properties of $P$. barbatus can probably be attributed to terpenoids.

Surveys carried out in Uganda, Tanzania and Namibia on the use of medicinal plants for HIVIAIDS treatment revealed $P$. barbatus as one of the commonly used herbal remedies in managing HIVIAIDS and the associated opportunistic infections. The aerial parts of this plant are administered orally by traditional medicine practitioners as a decoction or an infusion to treat HIVIAIDS, oral candidiasis, herpes simplex, hepes zoster and skin rashes(Chinsembu and Hedimbi, 2010; Kisangau et al., 2011, 2007; Lamorde et al., 2010). Exactly what the mechanism of action of the extract is, or why patients experience alleviation of symptoms (during or after its use) is unknown. Because HIV replicates in a highly oxidized environment (Gil del Valle et al., 2013), demonstrating substantial natural antioxidant activity in in vitro extracts of $P$. barbatus will contribute some mechanistic information. Also, direct anti-viral (as in the inhibition of viral enzymes) or anti-inflammatory activities, if exhibited by the extract, presents explanations for how the plant may slow disease progression. To be entirely useful, if the preceding effects exist, these abilities must go hand in hand with a lack of, or very low cytotoxicity.

HIV infected individuals even when successfully treated with highly active anti-retroviral therapy (HAART), continue to deal with incidences of malignancy, cardiovascular disease (CVD), metabolic, bone, renal and liver disease, very much like aging populations (Nixon and Landay, 2010). There is also ample evidence supporting the notion that inflammation plays a role in these conditions in the general population, while also having become leading causes of morbidity and mortality in HIV-infected individuals in settings where HAART is routinely used. Compared with the general population, high-sensitivity C-reactive protein (hs-CRP), interleukin 6 (IL-6), d-dimer, and certain other inflammatory biomarkers are significantly elevated during HIV infection (Nixon and Landay, 2010). Any product/compound that decreases these types of inflammatory biomarkers therefore has a potential use in improving the quality of life of infected individuals. The balance between the pro-inflammatory cytokines IL-1, IL-6 and tumor necrosis factor-alpha, which up-regulate HIV expression, and IL-10, which can act both as an anti-inflammatory cytokine and a B-cell stimulatory factor plays an 
important role in the progression to AIDS (Breen, 2002). Because HIVIAIDS is also known to affect IFN and IL-17 (Williams et al., 2013) where their levels serve as indicators of disease progression, the anti-inflammatory behaviour of the extract was investigated by assessing its effect on all the mentioned relevant pro-inflammatory cytokines simultaneously.

The aims of this study were therefore the investigation of the HIV-1 inhibitory properties, cytotoxicity, anti-inflammatory and antioxidant abilities of $P$. barbatus in order to determine whether the traditional claims are supported by actual pharmacological effects. The idea was to link the HIVIAIDS ethnomedicinal use of the plant to in vitro studies in order to validate the anecdotal claims in favour of $P$. barbatus. A lot of work has been done on $P$. barbatus; there is however nothing published on how or why extracts of this plant may be specifically assisting HIVIAIDS patients.

\section{Material and methods}

\subsection{Plant material}

Plectranthus barbatus Andr. leaves $(74.8 \mathrm{~g})$ were collected at the Botanical garden of the University of Pretoria during April 2011. Plant identification was done in the H.G.W.J Schweikerdt herbarium of the University and a voucher specimen (117198) is kept in the herbarium.

\subsection{Extraction}

Fresh leaves were blended in ethanol and filtered. The filtrate was concentrated under reduced pressure at $50{ }^{\circ} \mathrm{C}$. The residue was re-dissolved in ethyl acetate to exclude highly polar tannin compounds, non-specific enzyme inhibitors. The ethyl acetate fraction (lipophilic fraction) was dried and stored in the dark at $4{ }^{\circ} \mathrm{C}$ until use. The ethyl acetate extract was reconstituted in dimethyl sulfoxide (DMSO), which provides a sterile environment, before each biological assay. Further dilutions to obtain desired extract concentrations were done in either cell culture media for cytotoxicity or buffer for HIV-1 enzyme assays.

\subsection{Cytotoxicity assay using MTT and Real time cell sensing}

Tetrazolium dye 3-(4,5-dimethylthiazol-2-yl)-2,5-diphenyltetrazolium bromide (MTT) was used to assess the cytotoxicity of $P$. barbatus in TZM-bl cells (Mosmann, 1983). Briefly, 
cells were seeded in a 96-well tissue culture treated plate at $1 \times 10^{4}$ cells per well in the absence or presence of various gradient $P$. barbatus extract concentrations (100-3.125 $\mu \mathrm{g} / \mathrm{ml}$ ). Incubation was carried out for $72 \mathrm{~h}$ at $37{ }^{\circ} \mathrm{C}$ in humidified air with $5 \% \mathrm{CO}_{2}$. Auranofin was used as a positive control for cytotoxicity because it is a known toxic compound with antitumor activity (Mirabelli et al., 1985). Other control wells included a negative control (cells \& medium only), background control for extract and a DMSO control. Plates were read on a Multiskan Ascent reader at 550/690 $\mathrm{nm}$. The 50\% cytotoxic concentration $\left(\mathrm{CC}_{50}\right)$ was calculated using Graphpad Prism (Graphpad Software Inc. California, USA).

In addition to using MTT for the detection of cytotoxicity a real time-cell electronic sensing (RT-CES) device, xCelligence (Roche Diagnostics, Mannheim, Germany) was used to monitor proliferation of the TZM-bl cells in the presence of $P$. barbatus extract. The system monitors cellular events in real time without the incorporation of labels by measuring electrical impedance across interdigitated gold micro-electrodes integrated on the bottom of special tissue culture plates. Increasing attachment of cells to the electrodes increases electrode impedance which is displayed as Cell Index (CI) (Abassi et al., 2009; Atienzar et al., 2011). TZM-bl cells were seeded at $1 \times 10^{4}$ cells per well. Three concentrations of $P$. barbatus extract $(100,50.4$ and $25 \mu \mathrm{g} / \mathrm{ml}$ ) were tested alongside $10 \mu \mathrm{M}$ auranofin, positive control for toxicity. An untreated TZM-bl cells control was also included. Cell treatment monitoring was carried out over a period of 72 h.

\subsection{Effect of the extract on PBMC proliferation}

Ethical approval for obtaining blood samples from consenting donors was granted by the Faculties of Natural and Agricultural Sciences and Health Sciences Ethics Committees (EC080506-019; 163/2008, University of Pretoria, South Africa). Freshly isolated uninfected and infected PBMCs were plated in 96 well plates (Costar, Corning Incorporated, USA) at $1 \times 10^{5}$ cells per well and treated with the extract at final concentrations of $100,50,25,12.5,6.25$ and $3.125 \mu \mathrm{g} / \mathrm{ml}$. The number of viable cells was detected after $72 \mathrm{~h}$ using 3-(4,5-dimethylthiazol-2-yl)-5-(3-carboxymethoxyphenyl)2-(4-sulfophenyl)-2H-tetrazolium, inner salt (MTS) solution (Promega, Promega Corporation, USA). Control wells included a toxicity control auranofin (Mirabelli et al., 1985 ) and the plates were read at $492 / 690 \mathrm{~nm}$. The percentage viability was calculated relative to an untreated control of cells only and the $\mathrm{CC}_{50}$ values were determined using Graphpad Prism (Graphpad Software Inc. California, USA). 
The flow cytometric analysis of lymphocyte proliferation was measured using carboxylfluorecein succinimidyl ester (CFSE). The technique monitors the effect of a treatment, in this case extract, on mitotic activity of the T cell population based on the visualisation of eight to 10 discrete cycles of cell division (Fulcher and Wong, 1999; Lyons, 2000). HIV negative and positive PBMCs were labelled with CFSE and extract treatment of the labelled cells was done at two concentrations $(100$ and $50 \mu \mathrm{g} / \mathrm{ml})$ for 72 h. Prior to flow cytometric analysis, propidium iodide was incorporated to exclude background staining from dead cells (Fonteh et al., 2011). Data was acquired on a FACSAria (BD BioSciences, California, USA) and analysed using FlowJo Version 7.6.1 (TreeStar Inc., Oregon, USA).

\subsection{HIV-1 Protease fluorogenic assay}

This assay was a modified version of the assay performed by Lam et al. (2000). The fluorogenic HIV protease (PR) substrate 1 (Arg-Glu(EDANS)-Ser-Gln-Asn-Tyr-Pro-lleVal-GIn-Lys(DABCYL)-Arg) was dissolved in DMSO to make a $1 \mathrm{mM}$ stock. The stock fluorogenic substrate was diluted to $10 \mu \mathrm{M}$ using assay buffer $(0.1 \mathrm{M}$ sodium acetate, 1 $\mathrm{M} \mathrm{NaCl}, 1 \mathrm{mM}$ EDTA and $1 \mathrm{mM}$ DTT, $\mathrm{pH} 4.7)$. An aliquot of the substrate $(10 \mu \mathrm{M}, 49 \mu \mathrm{l})$ and $1 \mu \mathrm{l}$ of HIV-1 PR solution ( $1 \mu \mathrm{g} / \mathrm{ml}$; Bachem, Switzerland) were added to the reaction mixture in an assay buffer in the presence or absence (untreated control) of the extract to make a final reaction volume of $100 \mu \mathrm{l}$. The mixture was incubated at $37{ }^{\circ} \mathrm{C}$ for $1 \mathrm{~h}$ in black 96 well assay plates. The fluorescence intensity was measured at an excitation wavelength of $355 \mathrm{~nm}$ and an emission wavelength of $460 \mathrm{~nm}$ using a synergy microplate spectrofluorometer (BioTek, Analytical \& Diagnostic products, South Africa). Acetyl pepstatin (AP) was used as a positive control for HIV-1 PR inhibition. The blank treatment consisted of assay buffer with only the substrate and an untreated control of enzyme and substrate was also included. The percentage inhibition was calculated based on the formula: 100 - [(Test reagent RFU - background $\mathrm{RFU}) /($ untreated control RFU - blank) $\times 100$ ] where RFU = relative fluorescence units.

\subsection{HIV-1 reverse transcriptase colorimetric assay}

The effect of the crude extract on reverse transcription was tested using a reverse transcriptase (RT) colorimetric assay kit from Roche Diagnostics (Mannheim, Germany) and purified recombinant HIV-1 RT (Merck, Darmstadt, Germany). The assay was performed according to a method previously described (Fonteh et al., 2009). Extract was tested at two concentrations 100 and $50 \mu \mathrm{g} / \mathrm{ml}$. The enzyme $(0.2 \mathrm{U})$ was incubated 
for $1 \mathrm{~h}$ with the extract at $37^{\circ} \mathrm{C}$. Subsequent $1 \mathrm{~h}$ incubations involved addition of an antibody conjugated to peroxidase that binds to the digoxigenin-labeled DNA. In the final step, the peroxidase substrate solution [2,2'-azino-bis-(3-ethylbenzthiazoline-6sulfonic acid)] is cleaved by the peroxidase enzyme, producing a colored reaction product. Two positive controls were used; doxorubicin, a known HIV-1 RT inhibitor (Kuete et al., 2010b; Mbaveng et al., 2011) and an in-house natural product inhibitor active against HIV-1 RT (Fonteh et al., 2009). The absorbance of the samples was read at $405 \mathrm{~nm}$ with a reference wavelength of $492 \mathrm{~nm}$ using a microtiter plate reader (Multiskan Ascent; Thermo Labsystems; USA) and was directly correlated to the level of RT activity in the sample.

\subsection{Antioxidant activity: DPPH free radical scavenging assay}

The free radical scavenging activity of the extract was evaluated using a modified method previously described by Kuete et al. (2010). The extract dissolved in ethanol was mixed with a $90 \mu \mathrm{M}$ 2,2-diphenyl-1-picrylhydrazyl (DPPH) ethanol solution to give final extract concentrations of 6-100 $\mu \mathrm{g} / \mathrm{ml}$. Incubation of extract with DPPH was done in the dark at room temperature for $30 \mathrm{~min}$. The absorbance values were measured at 550 nm (Multiskan Ascent; Thermo Labsystems; USA) and converted into percentage of antioxidant activity (Marxen et al., 2007). A known antioxidant, ascorbic acid, was used as a standard control. $I_{50}$ values were calculated using Graphpad Prism (Graphpad Software Inc. California, USA).

\subsection{Anti-inflammatory activity: Cytometric bead array}

The effect of the extract on cytokine production was evaluated using the Human Th1/Th2/Th17 cytometric bead array (CBA) kit (BD Biosciences, San Jose, California) (Williams et al., 2013).

PBMCs were isolated from blood samples of healthy individuals $(n=4)$. Cells were seeded at a concentration of $1 \times 10^{6}$ cells per well and treated with two non-cytotoxic concentrations of the extract, 25 and $50 \mu \mathrm{g} / \mathrm{ml}$. The supernatant was collected after $24 \mathrm{~h}$ incubation and stored at $-20^{\circ} \mathrm{C}$ until cytokine analysis. Cytokine levels in the supernatant was analysed following the protocol outlined in the kit. The supernatant (50 $\mu \mathrm{l})$ was mixed with the cytokine capture beads and the detector reagent, phycoerythrin (PE)-conjugated detection antibodies, to form sandwich complexes. These complexes were measured using a FACSArray Bioanalyzer (BD Biosciences, San Jose, CA, USA) in order to identify the concentrations of specific cytokines. The limits of detection for 
each cytokine were as follow: $2.6 \mathrm{pg} / \mathrm{ml}$ for IL-2, $4.9 \mathrm{pg} / \mathrm{ml}$ for IL-4, $2.4 \mathrm{pg} / \mathrm{ml}$ for IL-6, $4.5 \mathrm{pg} / \mathrm{ml}$ for IL-10, $3.8 \mathrm{pg} / \mathrm{ml}$ for TNF, $3.7 \mathrm{pg} / \mathrm{ml}$ for IFN- $\gamma$ and $18.9 \mathrm{pg} / \mathrm{ml}$ for IL-17A.

\section{Results and discussion}

\subsection{Effect of $P$. barbatus extract on the viability of TZM-bl and PBMCs}

The $\mathrm{CC}_{50}$ of $P$. barbatus extract in TZM-bl cells using MTT was $50.4 \pm 2.7 \mu \mathrm{g} / \mathrm{ml}$ (Table 1) while RT-CES revealed a different cytotoxicity pattern. With RT-CES (Fig.1), 100 $\mu \mathrm{g} / \mathrm{ml}$ (iii) of the extract resulted in $<50 \%$ of TZM-bl cells being viable after $72 \mathrm{~h}$ compared to the control cells (i) and this was expected because of what was observed with MTT. The cell index for $100 \mu \mathrm{g} / \mathrm{ml}$ (iii) was low compared to that of control cells (i) indicating the reduction of cell viability at that concentration. Other concentrations tested; 50.4 (iv) and $25 \mu \mathrm{g} / \mathrm{ml}$ (v) were not toxic towards TZM-bl cells. $P$. barbatus has been reported to generally have low toxicity (Figueiredo et al., 2010) and the data obtained in the current study suggests that $P$. barbatus extract concentrations $\geq 100$ $\mu \mathrm{g} / \mathrm{ml}$ may result in high toxicity. The $\mathrm{CC}_{50}$ for Auranofin, positive control for toxicity, was $<10 \mu \mathrm{M}$ in TZM-bl and PBMCs.

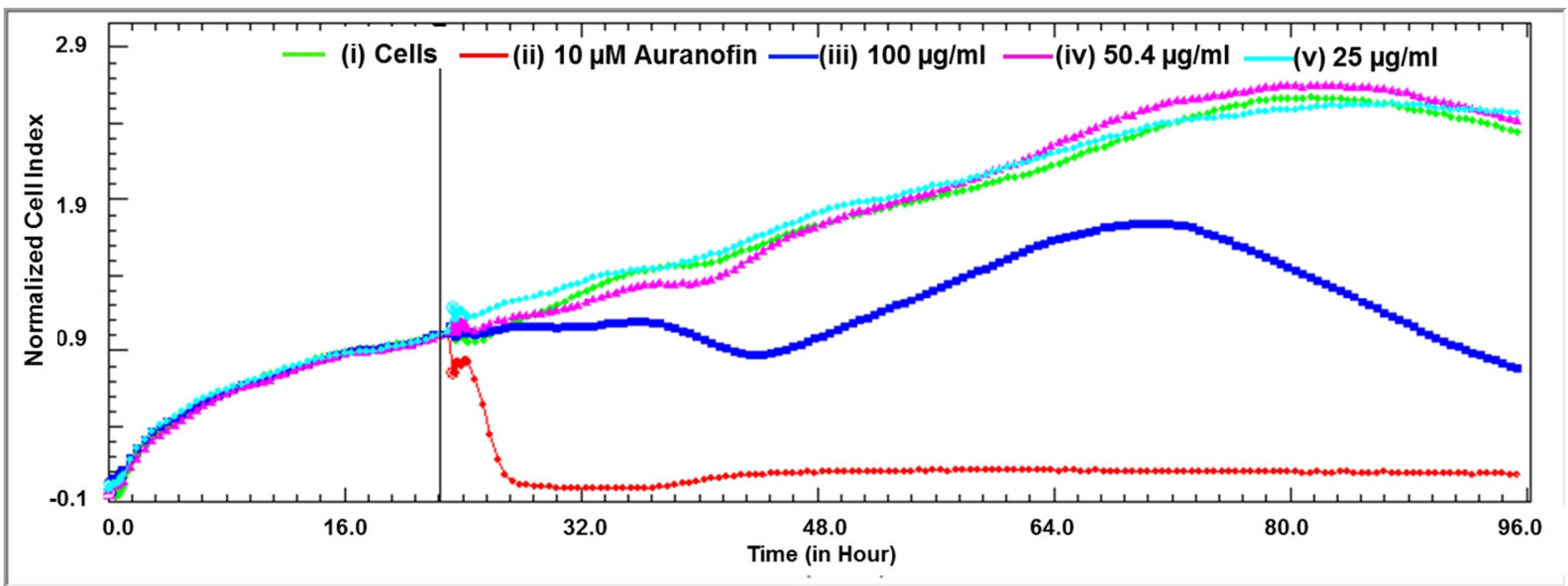

Fig.1. Effect of $P$. barbatus on TZM-bl cells as generated by real-time cell analysis. The cells were exposed to $100,50.4$ and $25 \mu \mathrm{g} / \mathrm{ml}$ of the extract and these are represented by the different colored curves. Auranofin (ii) was used as a positive control for toxicity. Each data point was normalized against the time point just before extract addition ( $24 \mathrm{~h}$ ).

$P$. barbatus was less toxic to PBMCs with a $\mathrm{CC}_{50}$ of $84.7 \pm 2.2 \mu \mathrm{g} / \mathrm{ml}$ (Table 1). These results were confirmed with flow cytometry whereby there was no significant difference $(p<0.05)$ in lymphocytes proliferation of untreated HIV negative $(-)$ PBMCs $(42 \%)$ and lymphocytes treated with $100 \mu \mathrm{g} / \mathrm{ml}$ of the extract (40\%). However, a marginally higher cell division of $47 \%$ was observed for lymphocytes treated with $50 \mu \mathrm{g} / \mathrm{ml}$ of the $P$. 
barbatus extract (Fig.2). Flow cytometry can be used on adherent or suspension cells while RT-CES is applicable to adherent cells, TZM-bl cells, explaining why the different techniques were applied for confirmation assays as they were.
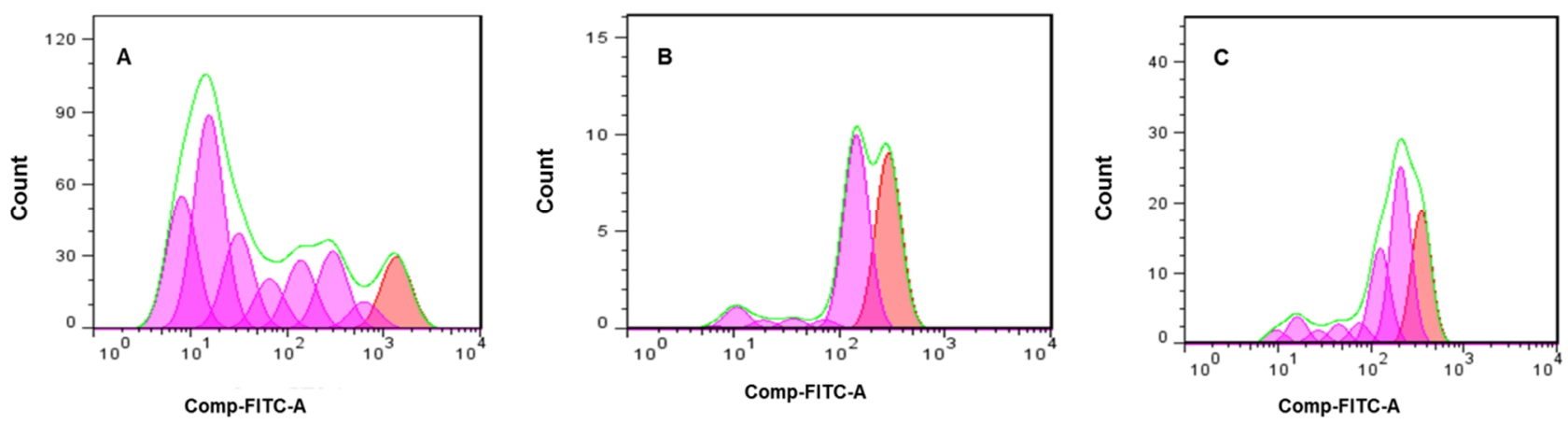

Fig.2. The 3 day response of CFSE-labelled HIV- PBMCs treated with the $P$. barbatus extract. The orange peak represents the parent cells and pink peaks are daughter populations as a result of cell division. (A) Cell division of $42 \%$ was observed in untreated PBMCs. (B) Parent cells of PBMCs treated with $100 \mu \mathrm{g} / \mathrm{ml}$ resulted in $40 \%$ division of parent to daughter cells. (C) PBMCs treated with $50 \mu \mathrm{g} / \mathrm{ml}$ of the extract had the highest cell division of $47 \%$.

A different trend was observed in HIV positive (+) lymphocytes (Fig.3); in the absence of the extract the control cells resulted in $19 \%$ cell division (compared to the $42 \%$ in uninfected, untreated cells) and a $2.8 \%$ cell division was observed with the parent cells of HIV+ lymphocytes treated with $100 \mu \mathrm{g} / \mathrm{ml}$ of the extract. A lymphocyte division of $54 \%$ was observed with cells treated with $50 \mu \mathrm{g} / \mathrm{ml}$ of the $P$. barbatus extract. The CFSE data suggests that the high extract concentration tested, $100 \mu \mathrm{g} / \mathrm{ml}$ (Fig.3B), was toxic to PBMCs while $50 \mu \mathrm{g} / \mathrm{ml}$ was less toxic (Fig.3C). CFSE analysis allowed for the tracking of daughter cells from the parent population of cells (Lyons, 2000) and the cell division into daughter cells was clearly observed. Lower concentrations of extract had a comparable proliferative effect on infected/uninfected cells. 

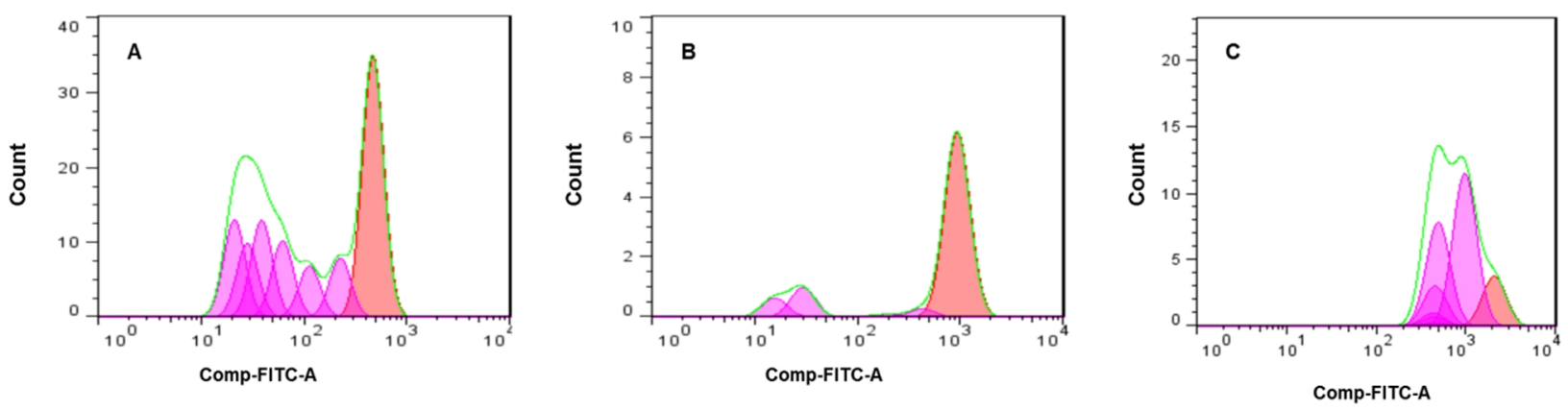

Fig.3. Effect of $P$. barbatus extract on the proliferation of CFSE-labelled HIV+ PBMCS. The orange peak represent the parent cells and pink peaks are daughter populations as a result of cell division. (A) \%cell division in control PBMCs was 19\% (B) Only $2.8 \%$ cell division was obtained with PBMCs treated with $100 \mu \mathrm{g} / \mathrm{ml}$ (C) A high cell division of $54 \%$ was observed in PBMCs treated with $50 \mu \mathrm{g} / \mathrm{ml}$ of the extract which was comparable to uninfected cells treated with a similar extract concentration.

Table 1. Cytotoxicity and HIV-1 inhibitory activities of $P$. barbatus ethanolic extract

\begin{tabular}{|c|c|c|c|c|}
\hline \multirow[t]{2}{*}{ Sample } & \multicolumn{2}{|c|}{$\mathrm{CC}_{50}(\mu \mathrm{g} / \mathrm{ml}) \pm \mathrm{SD}^{\mathrm{a}}$} & \multicolumn{2}{|c|}{$\mathrm{IC}_{50}(\mu \mathrm{g} / \mathrm{ml}) \pm \mathrm{SD}$} \\
\hline & TZM-bl & PBMCs & HIV-1 RT & HIV-1 PR \\
\hline P. barbatus & $50.4 \pm 2.7$ & $84.7 \pm 2.2$ & $>100$ & $62.0 \pm 0.2$ \\
\hline Auranofin ${ }^{b}$ & $<10$ & $<10$ & - & - \\
\hline Acetyl pepstatin ${ }^{c}$ & - & - & - & $<0.3$ \\
\hline Doxorubicin $^{d}$ & - & & $<25$ & \\
\hline $\mathrm{BBR}^{\mathrm{d}}$ & - & - & $0.3 \pm 0.1$ & - \\
\hline
\end{tabular}

\subsection{Anti-HIV-1 potential of $P$. barbatus}

P. barbatus extract inhibited HIV-1 PR, $70 \%$ inhibition, at $100 \mu \mathrm{g} / \mathrm{ml}\left(\mathrm{IC}_{50}=62.0 \pm 0.2\right.$ $\mu \mathrm{g} / \mathrm{ml}$ ) (Table 1). The lowest concentration tested, $50 \mu \mathrm{g} / \mathrm{ml}$, gave less than $50 \% \mathrm{HIV}-1$ PR inhibition. The positive control, acetyl pepstatin, inhibited HIV-1 PR by $97 \%$ at 10 $\mu \mathrm{g} / \mathrm{ml}$ and its $\mathrm{IC}_{50}$ was $<0.3 \mu \mathrm{g} / \mathrm{ml}$. The extract had weak inhibitory activity against HIV-1 RT (<50\%). Positive control for HIV-1 RT, doxorubicin, exhibited an $\mathrm{IC}_{50}<25 \mu \mathrm{g} / \mathrm{ml}$. The $I C_{50}$ of an in-house natural product inhibitor was $0.3 \pm 0.1 \mathrm{mg} / \mathrm{ml}$. These results suggests that the effectiveness of the traditional use of $P$. barbatus in managing HIVIAIDS (Chinsembu and Hedimbi, 2010; Kisangau et al., 2011; Lamorde et al., 2010) 
could be through the inhibition of HIV-1 PR. The use of herbal remedies for HIVIAIDS treatment is widely practised traditionally and it is of utmost importance to test the efficacy of plants used, in this case $P$. barbatus. There is no literature reporting the in vitro anti-HIV-1 activity of $P$. barbatus, making this study the first to link the in vitro inhibition of HIV-1 protease to the traditional use of this plant in HIVIAIDS treatment. Inhibition of HIV-1 PR could be attributed to diterpenoid compounds which are often described as the active ingredients identified in $P$. barbatus (Alasbahi and Melzig, 2010a, 2010b).

\subsection{Antioxidant properties of P. barbatus}

The results of the antioxidant activity of $P$. barbatus extract summarized in Fig. 4 showed a dose-dependent response. The $\mathrm{IC}_{50}$ of the extract was $15.8 \pm 0.3 \mu \mathrm{g} / \mathrm{ml}$ and vitamin $\mathrm{C}$, the positive control, had an $\mathrm{IC}_{50}$ of $1.1 \pm 0.02 \mu \mathrm{g} / \mathrm{ml}$. The $\mathrm{IC}_{50}$ value of $P$. barbatus obtained in this study was twice lower than that previously reported by Maioli et al. (2010), where an $\mathrm{IC}_{50}$ of $35.8 \pm 0.3 \mu \mathrm{g} / \mathrm{ml}$ was obtained in aqueous leaves extract of $P$. barbatus using a similar DPPH assay.

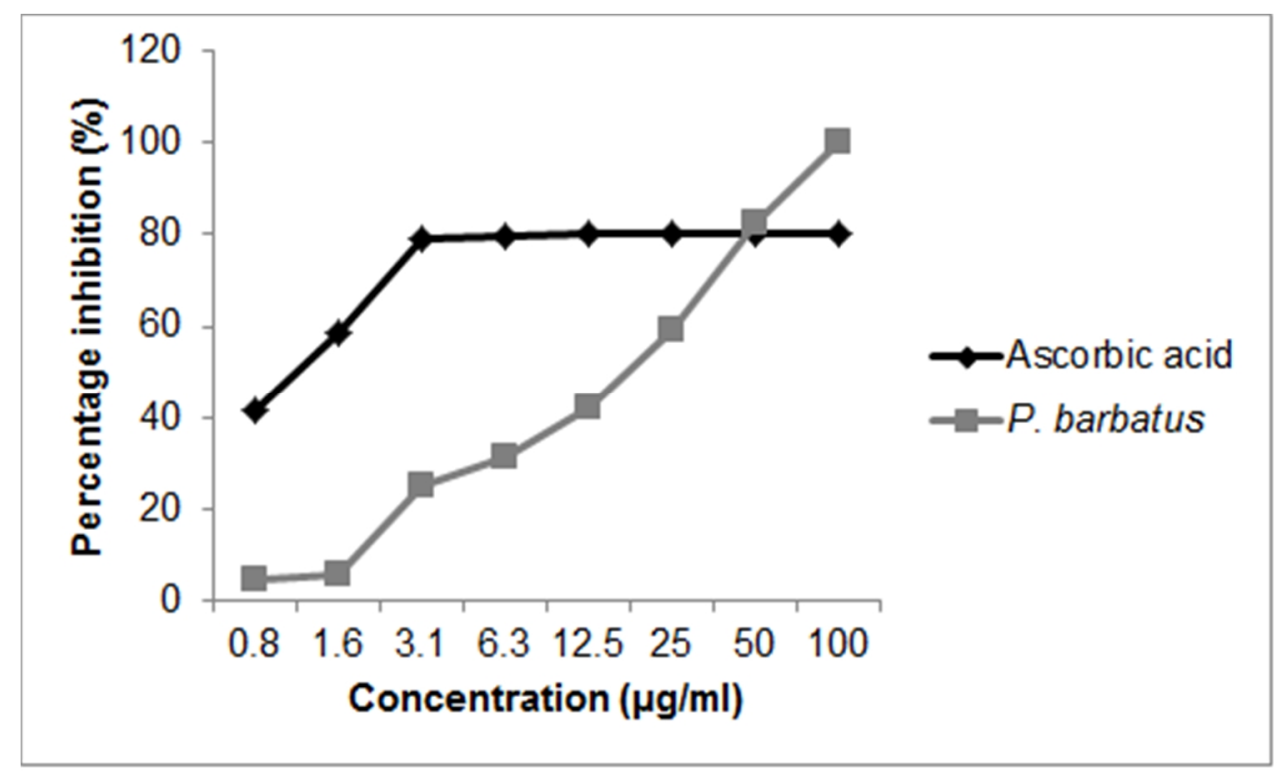

Fig.4. DPPH antioxidant potential of $P$. barbatus extract. Ascorbic acid was used as a positive control. $\mathrm{IC}_{50} \mathrm{~S}$ were $15.8 \pm 0.3$ and $1.1 \pm 0.02 \mu \mathrm{g} / \mathrm{ml}$ for extract and ascorbic acid respectively.

The good antioxidant properties of $P$. barbatus possibly contribute to the reduction of the viral load in HIV-infected patients that traditionally uses this plant. Oxidative stress, which is caused by the accumulation of reactive oxygen species, has been linked to the activation of HIV-1 leading to the development of AIDS (Gil del Valle et al., 2013; Gil et al., 2003; Vaira et al., 1990). Antioxidants such as vitamin $E$ and $C$ have been shown to 
reduce oxidative stress in HIV patients and in the process contribute towards a reduction in viral load (Allard et al., 1998).

\subsection{P. barbatus inhibits pro-inflammatory cytokines}

The two non-cytotoxic concentrations of $P$. barbatus tested, 50 and $25 \mu \mathrm{g} / \mathrm{ml}$, resulted in the reduction of cytokine production for all cytokines tested including pro-inflammatory cytokines IL-2, IL-6, IL-10, TNF and IL-17A (Fig.5).
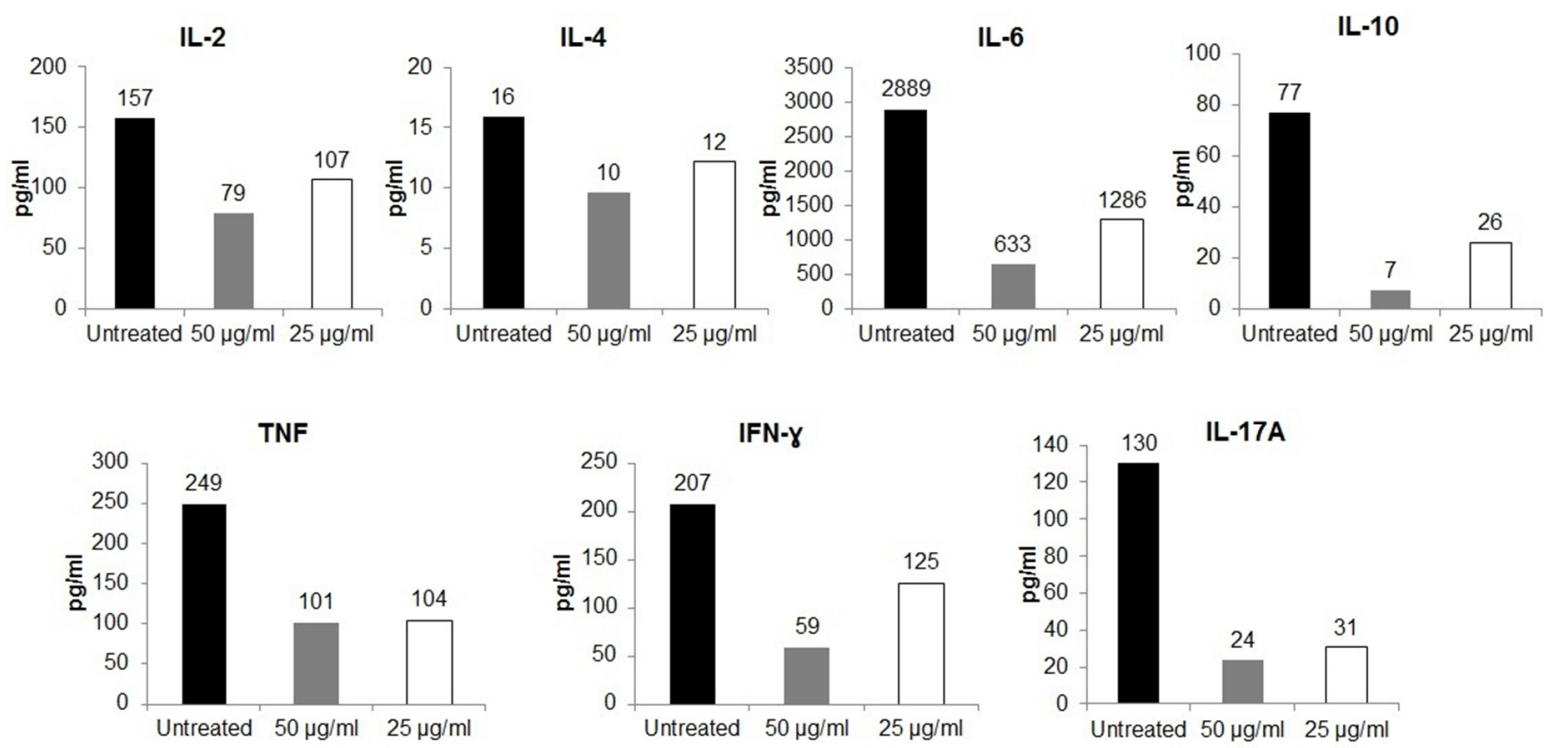

Fig.5 Effect of $P$. barbatus extract on cytokine production in PBMCs. The values are mean cytokine concentrations of PBMCs from 4 HIV negative individuals. Cells were exposed to medium only (untreated control) and two non-cytotoxic concentrations of the extract, 50 and $25 \mu \mathrm{g} / \mathrm{ml}$. The extract significantly ( $p$ $<0.05$ ) reduced the production of IL-2, IL-6, IL-10, TNF, IFN- $y$ and IL-17A.

The ability of $P$. barbatus extract to inhibit inflammatory cytokines can be linked to its traditional use in treating various ailments (Lukhoba et al., 2006). Anti-inflammatory properties were previously detected by Matu and Staden (2003) in P. barbatus from Kenya when the methanolic extract of the leaves inhibited cyclooxygenase (COX-1), an enzyme involved in the cascade of events resulting in pain and inflammation. The current study identified another anti-inflammatory mechanism of $P$. barbatus which is through the inhibition of pro-inflammatory cytokines. These results can also be linked to anti-HIV properties of this plant; low levels of IL-17A in HIV-1 infection is associated with non-progression (Yue et al., 2008). IL-17A along with other cytokines such as IL-2 and IL-6 are elevated during the different stages of HIV infection (Keating et al., 2011; Nixon and Landay, 2010; Worsley et al., 2010; Yue et al., 2008). Therefore lowering the production of this cytokines especially IL-17A could contribute to slow or non- 
progression of HIV infection. The IFN- $\gamma$ paradox in HIV infection needs better understanding. There is a need to control antiretroviral effects of IFN- $\gamma$ during HIV infection. The ability of the extract in this study to lower IFN- $\gamma$ production can possibly be of clinical importance during late stages of HIV infection. High levels of IFN- $\gamma$ have been detected during progression of HIV to AIDS with no reported anti-HIV effect (Abel et al., 2002; Biswas et al., 1992; Francis et al., 1992). From data presented here it seems possible that $P$. barbatus ingestion contributes to a slower disease progression during HIV infection by inhibiting cytokines involved in this pathogenesis.

The in vitro anti-HIV-1 data obtained in this study is the first for $P$. barbatus. The ability of $P$. barbatus to inhibit HIV-1 protease confirms the ethnobotanical claims of this plant and supports its continuous traditional use in managing HIVIAIDS and associated opportunistic infections. Synergistic interactions between compounds in crude extracts have been reported to occur (Ma et al., 2009). Hence, the need to first test crude extracts before purification of bioactive compounds. The study shows that $P$. barbatus extract contain inhibitory compounds active against HIV-1 PR. Since the chemistry of $P$. barbatus has been vastly reported in the past 30 years, it will be of interest for further investigation to be carried out through in silico analysis of the compounds isolated from $P$. barbatus. Further work will also involve purification of the active ingredient (s) in order to determine the exact mechanism of action that occurred with HIV-1 PR inhibition which seems to aid in the health of HIVIAIDS patients treated with that plant.

\section{Acknowledgments}

This research was supported by the Southern African Biochemistry and Informatics for Natural Products (SABINA), the Technology Innovation Agency (TIA) of South Africa), Margaret McNamara Memorial Fund (MMMF), the Namibian Ministry of Education and the University of Pretoria.

\section{References}

Abassi, Y.A., Xi, B., Zhang, W., Ye, P., Kirstein, S.L., Gaylord, M.R., Feinstein, S.C., Wang, X., Xu, X., 2009. Kinetic cell-based morphological screening: prediction of mechanism of compound action and off-target effects. Chemistry and Biology 16, 712-723. 
Abdel-Mogib, M., Albar, H.A., Batterjee, S.M., 2002. Chemistry of the genus Plectranthus. Molecules 7, 271-301.

Abel, K., Alegria-hartman, M.J., Marthas, M., Miller, C.J., 2002. The relationship between simian immunodeficiency virus RNA levels and the mRNA levels of alpha / beta interferons (IFN- $\alpha / \beta$ ) and IFN- $\alpha / \beta$-inducible $M x$ in lymphoid tissues of Rhesus Macaques during acute and chronic infection. Journal of Virology 76, 8433-8445.

Alasbahi, R.H., Melzig, M.F., 2010a. Plectranthus barbatus: a review of phytochemistry, ethnobotanical uses and pharmacology - part 1. Planta Medica 76, 653-661.

Alasbahi, R.H., Melzig, M.F., 2010b. Plectranthus barbatus: a review of phytochemistry, ethnobotanical uses and pharmacology - part 2. Planta Medica 76, 753-765.

Allard, J.P., Aghdassi, E., Chau, J., Tam, C., Kovacs, C.M., Salit, I.E., Walmsley, S.L., 1998. Effects of vitamin $E$ and $C$ supplementation on oxidative stress and viral load in HIV-infected subjects. AIDS 12, 1653-1659.

Almeida, F.B.S., 2003. Antispasmodic effect of the essential oil of Plectranthus barbatus and some major constituents on the guinea-pig ileum. Planta Medica 69, 10801085.

Atienzar, F.A., Tilmant, K., Gerets, H.H., Toussaint, G., Speeckaert, S., Hanon, E., Depelchin, O., Dhalluin, S., 2011. The use of real-time cell analyzer technology in drug discovery: defining optimal cell culture conditions and assay reproducibility with different adherent cellular models. Journal of Biomolecular Screening 16, 575587.

Biswas, P., Poli, G., Kinter, A.L., Justement, J.S., Stanley, S.K., Maury, W.J., Bressler, P., Orenstein, J.M., Fauci, A.S., 1992. Interferon $\gamma$ induces the expression of human immunodeficiency virus in persistently infected promonocytic cells (U1) and redirects the production of virions to intracytoplasmic vacuoles in phorbol myristate acetate-differentiated U1 cells. The Journal of Experimental Medicine 176, 739750.

Breen, E.C., 2002. Pro- and anti-inflammatory cytokines in human immunodeficiency virus infection and acquired immunodeficiency syndrome. Pharmacology \& Therapeutics 95, 295-304.

Chinsembu, K.C., Hedimbi, M., 2010. An ethnobotanical survey of plants used to manage HIVIAIDS opportunistic infections in Katima Mulilo, Caprivi region, Namibia. Journal of Ethnobiology and Ethnomedicine 6, 1-9.

Figueiredo, N.L., Raquel, S., Aguiar, M.M. De, Luis, P., Ascensão, L., Luisa, M., Serralheiro, M., Rosa, A., Lino, L., 2010. The inhibitory effect of Plectranthus barbatus and Plectranthus ecklonii leaves on the viability, glucosyltransferase activity and biofilm formation of Streptococcus sobrinus and Streptococcus mutans. Food Chemistry 119, 664-668.

Fonteh, P.N., Keter, F.K., Meyer, D., 2011. New bis(thiosemicarbazonate) gold(III) complexes inhibit HIV replication at cytostatic concentrations: potential for incorporation into virostatic cocktails. Journal of Inorganic Biochemistry 105, 117380.

Fonteh, P.N., Keter, F.K., Meyer, D., Guzei, I.A., Darkwa, J., 2009. Tetra-chloro-(bis(3,5-dimethylpyrazolyl)methane)gold(III) chloride: an HIV-1 reverse transcriptase and protease inhibitor. Journal of Inorganic Biochemistry 103, 190-194.

Francis, M.L., Meltzer, M.S., Howard, G.E., 1992. Interferons in the persistence, pathogenesis, and treatment of HIV infection. AIDS Research and Human Retroviruses 8, 199-207.

Fulcher, D., Wong, S., 1999. Carboxyfluorescein succinimidyl ester-based proliferative assays for assessment of $\mathrm{T}$ cell function in the diagnostic laboratory. Immunology and Cell Biology 77, 559-564. 
Gil del Valle, L., Hernández, R.G., Ávila, J.P., 2013. Oxidative stress associated to disease progression and toxicity during antiretroviral therapy in human immunodeficiency virus infection. Journal of Virology and Microbiology 2013.

Gil, L., Mart, G., González, I., Tarinas, A., Álvarez, A., Giuliani, A., Molina, R., Tápanes, R., Pérez, J., Sonia, O., 2003. Contribution to characterization of oxidative stress in HIVIAIDS patients. Pharmacological Research 47, 217-224.

Keating, S.M., Golub, E.T., Nowicki, M., Young, M., Anastos, K., Crystal, H., Cohen, M.H., Zhang, J., Greenblatt, R.M., Desai, S., Wu, S., Landay, A.L., Gange, S.J., Norris, P.J., 2011. The effect of HIV infection and HAART on inflammatory biomarkers in a population-based cohort of women. AIDS 25, 1823-32.

Kisangau, D.P., Herrmann, T.M., Lyaruu, V.M., Hosea, K.M., Joseph, C.C., Mbwambo, Z.H., Masimba, P.J., 2011. Traditional knowledge, use practices and conservation of medicinal plants for HIVIAIDS care in rural Tanzania. Ethnobotany Research and Applications 9, 43-57.

Kisangau, D.P., Lyaruu, H.V.M., Hosea, K.M., Joseph, C.C., 2007. Use of traditional medicines in the management of HIV/AIDS opportunistic infections in Tanzania: a case in the Bukoba rural district. Journal of Ethnobiology and Ethnomedicine 8, 18.

Kuete, V., Metuno, R., Keilah, P.L., Tshikalange, E.T., Ngadjui, B.T., 2010a. Evaluation of the genus Treculia for antimycobacterial, anti-reverse transcriptase, radical scavenging and antitumor activities. South African Journal of Botany 76, 530-535.

Kuete, V., Ngameni, B., Mbaveng, A T., Ngadjui, B., Meyer, J.J.M., Lall, N., 2010b. Evaluation of flavonoids from Dorstenia barteri for their antimycobacterial, antigonorrheal and anti-reverse transcriptase activities. Acta Tropica 116, 100-4.

Lam, T.L., Lam, M.L., Au, T.K., Ip, D.T.M., Ng, T.B., Fong, W.P., Wan, D.C.C., 2000. A comparison of human immunodeficiency virus type-1 protease inhibition activities by the aqueous and methanol extracts of Chinese medicinal herbs. Life Sciences 67, 2889-2896.

Lamorde, M., Tabuti, J.R.S., Obua, C., Kukunda-byobona, C., Lanyero, H., Byakikakibwika, P., Bbosa, G.S., Lubega, A., Ogwal-okeng, J., Ryan, M., Waako, P.J., Merry, C., 2010. Medicinal plants used by traditional medicine practitioners for the treatment of HIVIAIDS and related conditions in Uganda. Journal of Ethnopharmacology 130, 43-53.

Lukhoba, C.W., Simmonds, M.S.J., Paton, A.J., 2006. Plectranthus: a review of ethnobotanical uses. Journal of Ethnopharmacology 103, 1-24.

Lyons, A.B., 2000. Analysing cell division in vivo and in vitro using flow cytometric measurement of CFSE dye dilution. Journal of Immunological Methods 243, 147154.

Ma, X.H., Zheng, C.J., Han, L.Y., Xie, B., Jia, J., Cao, Z.W., Li, Y.X., Chen, Y.Z., 2009. Synergistic therapeutic actions of herbal ingredients and their mechanisms from molecular interaction and network perspectives. Drug Discovery Today 14, 579-88.

Maioli, M.A., Alves, L.C., Campanini, A.L., Lima, M.C., Dorta, D.J., Groppo, M., Cavalheiro, A.J., Curti, C., Mingatto, F.E., 2010. Iron chelating-mediated antioxidant activity of Plectranthus barbatus extract on mitochondria. Food Chemistry 122, 203-208.

Marxen, K., Vanselow, K.H., Lippemeier, S., Hintze, R., Ruser, A., Hansen, U., 2007. Determination of DPPH radical oxidation caused by methanolic extracts of some microalgal species by linear regression analysis of spectrophotometric measurements. Sensors 7, 2080-2095.

Matu, E.N., Staden, J. Van, 2003. Antibacterial and anti-inflammatory activities of some plants used for medicinal purposes in Kenya. Journal of Ethnopharmacology 87, 35-41. 
Mbaveng, A.T., Kuete, V., Mapunya, B.M., Beng, V.P., Nkengfack, A.E., Meyer, J.J.M., Lall, N., 2011. Evaluation of four Cameroonian medicinal plants for anticancer, antigonorrheal and antireverse transcriptase activities. Environmental Toxicology and Pharmacology 32, 162-7.

Mirabelli, C.K., Johnson, R.K., Sung, C.M., Sung, C., Faucette, L., Muirhead, K., Crooke, S.T., 1985. Evaluation of the in vivo antitumor activity and in vitro cytotoxic properties of auranofin, a coordinated gold compound, in murine tumor models. Cancer Research 45, 32-39.

Mosmann, T., 1983. Rapid colorimetric assay for cellular growth and survival: application to proliferation and cytotoxicity assays. Journal of Immunological Methods 65, 55-63.

Nguta, J.M., Mbaria, J.M., Gakuya, D.W., Gathumbi, P.K., Kiama, S.G., $2010 a$. Antimalarial herbal remedies of Msambweni, Kenya. Journal of Ethnopharmacology $128,424-432$.

Nguta, J.M., Mbaria, J.M., Gakuya, D.W., Gathumbi, P.K., Kiama, S.G., $2010 b$. Traditional antimalarial phytotherapy remedies used by the South Coast community, Kenya. Journal of Ethnopharmacology 131, 256-267.

Nixon, D.E., Landay, A.L., 2010. Biomarkers of immune dysfunction in HIV. Current Opinion in HIV and AIDS 5, 498-503.

Rice, L.J., Brits, G.J., Potgieter, C.J., Staden, J. Van, 2011. Plectranthus: a plant for the future? South African Journal of Botany 77, 947-959.

Runyoro, D.K.B., Matee, M.I.N., Ngassapa, O.D., Joseph, C.C., Mbwambo, Z.H., 2006. Screening of Tanzanian medicinal plants for anti-Candida activity. BMC Complementary and Alternative Medicine 10, 1-10.

Vaira, D., Pincemail, J., De, A.V.A.N., 1990. Activation of human immunodeficiency virus type 1 by oxidative stress. AIDS Research and Human Retroviruses 6, 13891397.

Williams, A., Steffens, F., Reinecke, C., Meyer, D., 2013. The Th1/Th2/Th17 cytokine profile of HIV-infected individuals: a multivariate cytokinomics approach. Cytokine 61, 521-526.

Worsley, C.M., Suchard, M.S., Stevens, W.S., Van Rie, A., Murdoch, D.M., 2010. Multianalyte profiling of ten cytokines in South African HIV-infected patients with Immune Reconstitution Inflammatory Syndrome (IRIS). AIDS Research and Therapy 7, 36.

Yue, F.Y., Merchant, A., Kovacs, C.M., Loutfy, M., Persad, D., Ostrowski, M.A., 2008. Virus-specific interleukin-17-producing CD4+ T cells are detectable in early human immunodeficiency virus type 1 infection. Journal of Virology 82, 6767-71. 